\title{
Seismic retrofitting of timber framed walls
}

\author{
A.M. Gonçalves $\bowtie$, J. Gomes-Ferreira, L. Guerreiro, F. Branco \\ University of Lisbon, Instituto Superior Técnico, DECivil, ICIST \\ $\bowtie$ goncalves.amn@gmail.com
}

Received 31 July 2013

Accepted 7 November 2013

Available on line 2 D ecember 2014

\begin{abstract}
After the 1755 earthquake that destroyed Lisbon, an innovative anti-seismic structural system was developed consisting of a timber skeleton, that included timber framed masonry walls. After more than 250 years these structures need rehabilitation to face the present demands. The research presented in this paper aimed at experimentally characterizing the cyclic behaviour of timber framed walls reinforced with three different methods, namely: (i) elastic-plastic dampers on diagonal braces, (ii) reinforcement of timber connections with steel plates, (iii) application of a reinforced rendering. The elastic-plastic damper showed an unsymmetrical behaviour and some difficulties to implement in practice. The strengthening with reinforced render led to an initial stiffness increase but showed a limited deformation capacity. The walls with reinforcing steel plates at the timber connections showed the best behaviour in terms of strength, stiffness and energy dissipation.
\end{abstract}

KEYWORDS: Timber framed walls; Strengthening; Earthquake; Elastic-plastic dampers; Steel plates; Reinforced rendering

Citation / Citar como: Gonçalves, A.M.; Gomes-Ferreira, J.; Guerreiro, L.; Branco, F. (2014) Seismic retrofitting of timber framed walls. Mater. Construcc. 64 [316], e040 http://dx.doi.org/10.3989/mc.2014.06913.

RESUMEN: Refuerzo sismico de muros de mamposteria con entramado de madera. Después del terremoto de 1755 que destruyó Lisboa, un sistema estructural antisísmico muy innovador fue desarrollado. El sistema consistió en un esqueleto de madera, que incluyó la construcción de muros de mampostería con un entramado de madera. Transcurridos más de 250 años, estas estructuras necesitan rehabilitación para poder hacer frente a los requisitos estructurales actuales. La investigación presentada en este trabajo tiene como objetivo caracterizar experimentalmente el comportamiento cíclico de los muros con entramado de madera reforzados con tres métodos diferentes: (i) amortiguadores elasto-plásticos, (ii) refuerzo de las conexiones de madera con placas de acero, (iii) aplicación de un mortero reforzado. El amortiguador elasto-plástico mostró un comportamiento asimétrico y algunas dificultades para aplicarlo en la práctica. El refuerzo con mortero reforzado condujo a un aumento de la rigidez inicial, pero reveló una capacidad de deformación limitada. Los muros con placas de refuerzo de acero en las conexiones de madera mostraron el mejor comportamiento en términos de resistencia, rigidez y disipación de la energía.

PALABRAS CLAVE: Muros con entramado de madera; Refuerzo; Terremoto; Amortiguadores; Placas de acero; Mortero reforzado

Copyright: (C) 2014 CSIC. This is an open-access article distributed under the terms of the Creative Commons Attribution-Non Commercial (by-nc) Spain 3.0 License.

\section{INTRODUCTION}

After the large destruction of Lisbon due to the 1755 earthquake, the city had to be almost completely rebuilt. The innovative "pombaline" buildings, named after the Marquis of Pombal, the prime minister to date, were then developed. This type of building is characterized by its structural internal timber framed walls (TFW) in elevated floors, constituted by a timber frame with vertical 
and horizontal elements, braced with diagonal elements (Saint Andrew's crosses) with a masonry infill. These timber elements were connected to the floors' beams, forming a three-dimensional timber frame structure with improved stiffness and deformation capacity under seismic actions (1).

Most of these buildings presently need to undergo seismic rehabilitation due to the following reasons: (i) their natural degradation due to aging, (ii) the need for adaptation to the present serviceability conditions, generally involving structural changes, (iii) former interventions with elimination or damaging of structural elements, affecting seismic resistance, and (iv) noncompliance with the new generation of seismic codes (2).

Due to the lack of specific codes, the seismic rehabilitation of old buildings is usually carried out based on empirical rules, essentially depending on expertise and experience of designers and contractors. Actually, the lack of knowledge on the TFW seismic behaviour and on the effect of possible reinforcing solutions led to the absence of design procedures for seismic rehabilitation that could be generally accepted (3).

The main objective of the work presented in this paper is to contribute to the development of knowledge in the area of seismic rehabilitation and reinforcement of buildings with TFW. In these buildings, an adequate seismic strengthening strategy must comprise the reinforcement of the TFW, as they are a key structural element regarding horizontal loading. In this context, three different strengthening techniques of $\mathrm{TFW}$ are proposed and experimentally tested, namely: i) the use of elastic-plastic dampers, ii) steel plate reinforcement on timber elements' connections, and iii) reinforced render.

\section{EXPERIMENTAL PROGRAMME}

\subsection{Tested specimens}

The tested walls are constituted by four Saint Andrew's crosses. A total of seven walls were constructed and tested in the laboratory. Two specimens consist of non-reinforced timber framed wall modules, while the remaining walls were strengthened with the referred seismic rehabilitation methods based on elastic-plastic dampers, steel plate reinforcement and reinforced rendering (Figure 1). Table 1 summarizes the performed tests.

In the execution of models, assured by the construction and rehabilitation contractor "HCI Construções" the construction techniques used for the rehabilitation of such structures were reproduced. Cross-halving joints (Figure 2) were used in the connections between vertical and horizontal timber elements and between the crossing diagonals. The connections between the diagonals and their end nodes were obtained by simply sawing at $45^{\circ}$. All connections were reinforced with iron nails. The timber used was stone pine (pinus pinea), the timber frames presented a thickness of $12 \mathrm{~cm}$ and wood sections were: $16 \times 12 \mathrm{~cm}^{2}$ (base and top beam) and $8 \times 12 \mathrm{~cm}^{2}$ (all other elements) (Figure 1).

The masonry consists of bricks connected with cement-lime-sand mortar with a volume ratio of 1:2:6 (hydrated lime: portland cement $32.5 \mathrm{~N}$ : sand). Although ancient mortars were solely composed of lime and sand, cement was added in these cases to ensure a faster cure. The curing time, between the specimen fabrication and the experimental testing, was two months. Although the mortar composition is different from that of the ancient mortars, the overall results are expected to be similar to those obtained in certain ancient walls because: (i) the lime mortars undergo a stiffening process due to carbonation reactions and, after several centuries, their stiffness may be compared to that of a young lime-cement mortar, (ii) the behaviour of the wall masonry infill depends, not only on the mortar, but also on the ceramic elements, and (iii) the masonry infill in ancient timber-framed walls also varied in the mortar composition and the ceramic (or stone) type used and so the properties of the masonry infill used in the present tests surely lay within those variation limits.

\subsection{Experimental procedures}

The walls were subjected to cyclic quasi-static tests performed in the reaction wall at the Laboratory of Structures and Strength of Materials of the "Instituto Superior Técnico". The tests involved the application of an in-plane horizontal cyclic displacement history on the top of the models (shear testing) and of a constant vertical load to simulate gravity effects.

The horizontal displacements history followed the CUREE protocol (4). This history consists of cyclic displacement sequences increasing in amplitude throughout the test, each segment consisting of a primary cycle, with the amplitude defined as a multiple of the reference displacement $(\Delta)$, followed by a series of cycles with amplitude equal to $75 \%$ of the primary cycle (Table 2).

The reference displacement $\Delta$ was $90 \mathrm{~mm}$, corresponding to the maximum displacement obtained at experimental tests formerly performed at IST (5).

The horizontal displacements were imposed with a $1000 \mathrm{kN}$ capacity electrical screw jack actuator, electronically operated through a control unit.

The constant vertical load transmitted at the top of the elements to simulate gravity loads was applied by six steel cables tensioned with hydraulic jacks connected to an electronic pressure control system. The vertical loading to impose on the tested 

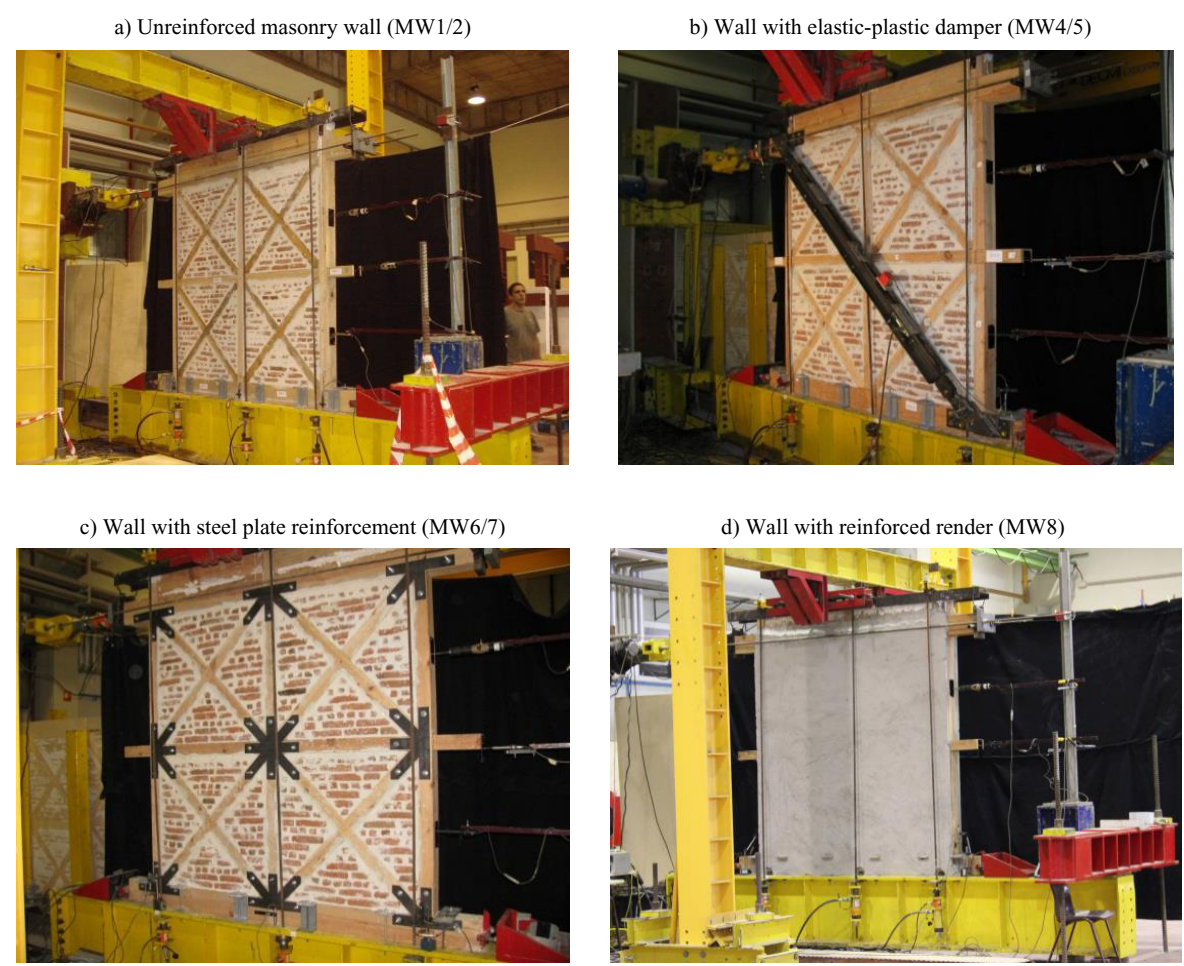

FiguRE 1. Timber framed masonry models with and without reinforcement.

walls was determined based on Eurocode 1 (6) and is given by equation [1], where $\mathrm{Sd}$ is the vertical loading, SW is the self-weight and LL is the live load. A load of $30 \mathrm{kN} / \mathrm{m}$ was estimated, considering a ground floor wall of a four storey building with a $5 \mathrm{~m}^{2}$ influence area.

$$
\mathrm{Sd}=\mathrm{SW}+0.3 \mathrm{LL}
$$

The walls were fully instrumented to measure the displacement at different points. The general layout of the equipment is shown in Figure 3. The displacement transducers D1 to D4 measured the horizontal displacement on the wall at different heights, D5 to D7 measured the vertical lift of the vertical timber element in regard to the bottom

TABLE 1. List of experimental tests

\begin{tabular}{lcc}
\hline Wall & $\begin{array}{c}\text { Number } \\
\text { of tests }\end{array}$ & Labelled \\
\hline Timber-masonry wall & 2 & MW1, MW2 \\
$\begin{array}{l}\text { Timber-masonry wall with } \\
\text { elastic-plastic damper }\end{array}$ & 2 & MW4, MW5 \\
$\begin{array}{l}\text { Timber-masonry wall with steel } \\
\text { plates }\end{array}$ & 2 & MW6, MW7 \\
$\begin{array}{c}\text { Timber-masonry wall with reinforced } \\
\text { render }\end{array}$ & 1 & MW8 \\
\hline
\end{tabular}

wood beam, D8 and D9 measured the displacement in the diagonals. The load imposed by the actuator was also measured with a load cell, as well as the tension load in the vertical cables used to impose the vertical load.

All load and displacement transducers and the screw jack control unit were connected to a National Instruments data logger operated through a personal computer were all test data was recorded.

\section{RESULTS AND DISCUSSION}

\subsection{Unreinforced timber framed walls}

The load-displacement diagrams obtained for the unreinforced masonry walls (MW1 and MW2) are shown in Figure 4. Figure 4a) shows the complete
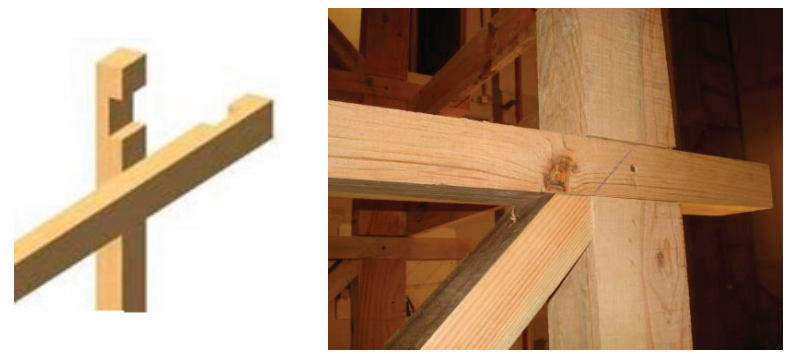

Figure 2. Cross-halving joints. 
TABle 2. Displacement history

\begin{tabular}{lcc}
\hline Segment & $\mathbf{N}^{\circ}$ of cycles & Amplitude in the primary cycle (\%) $\times \Delta$ \\
\hline 1 & 6 & $5 \% \times \Delta$ \\
2 & 7 & $7.5 \% \times \Delta$ \\
3 & 7 & $10 \% \times \Delta$ \\
4 & 4 & $20 \% \times \Delta$ \\
5 & 4 & $30 \% \times \Delta$ \\
6 & 3 & $40 \% \times \Delta$ \\
7 & 3 & $70 \% \times \Delta$ \\
8 & 3 & $100 \% \times \Delta$ \\
$9,10,11, \ldots$ & 3 & $(100 \%+100 \% \times \alpha) \times \Delta, \alpha=1,2,3, \ldots$
\end{tabular}

diagrams, while the Figure 4b) shows the diagrams corresponding only to displacement up to $60 \mathrm{~mm}$. An increase in the wall stiffness for displacements higher than $60 \mathrm{~mm}$ was observed. However, this boost in the stiffness is due to the increase of load in the tensioned cables when the attached jacks reach their limit course and these values cannot be taken into account for characterization of the walls. Then, the analysis is limited to a range of $\pm 55 \mathrm{~mm}$ displacements, which nevertheless results in a significant value of $2.6 \%$ drift.

The hysteretic behaviour of these walls subjected to cyclic loading is characterized by nonlinear behaviour with a high ductility response. The maximum strength within this cycles amplitude is about $50 \mathrm{kN}$ measured at the displacement of $55 \mathrm{~mm}$.

A certain vertical lift of the bottom beam together with a separation of the vertical timber element from the bottom beam occurred during the wall test as an effect of a rocking motion that was

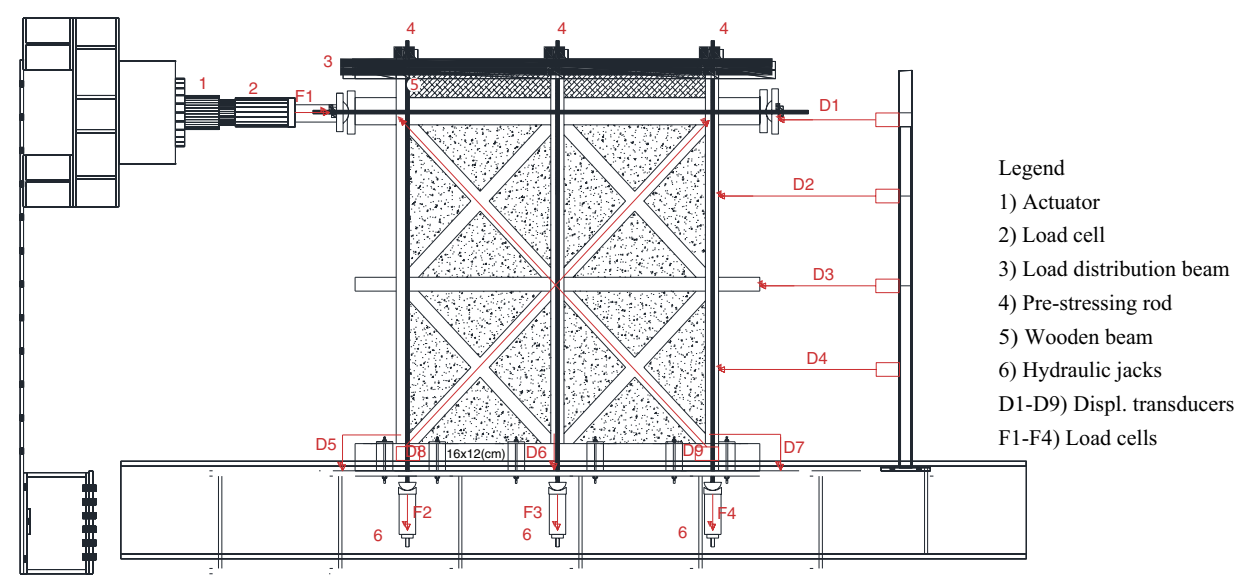

FIgURE 3. Test set-up.

a) Complete diagram

Drift (\%)

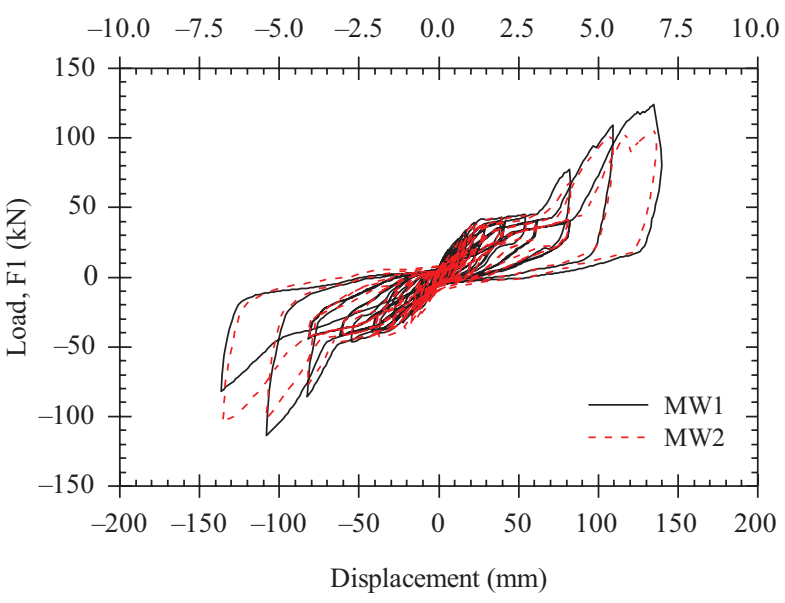

b) Diagram for displacement less than $60 \mathrm{~mm}$ Drift $(\%)$

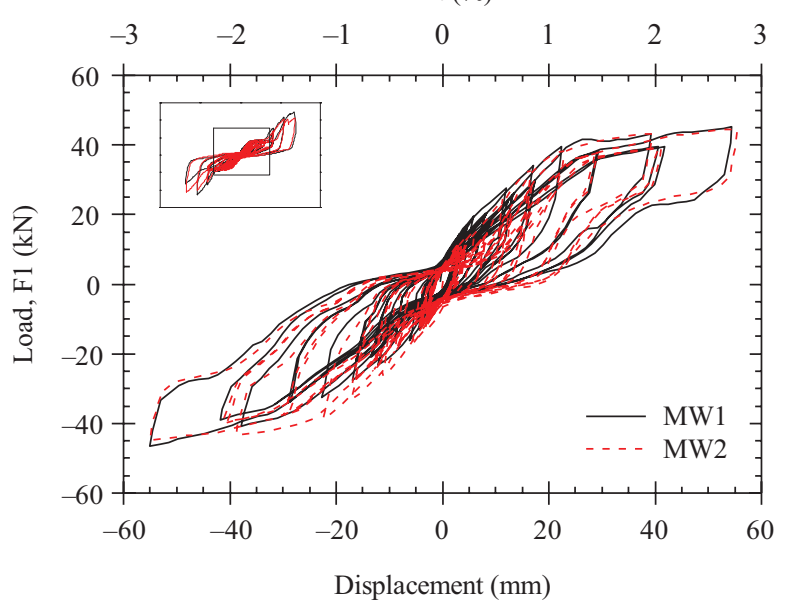

FIGURE 4. Load-displacement curves of MW1 and MW2 walls. 


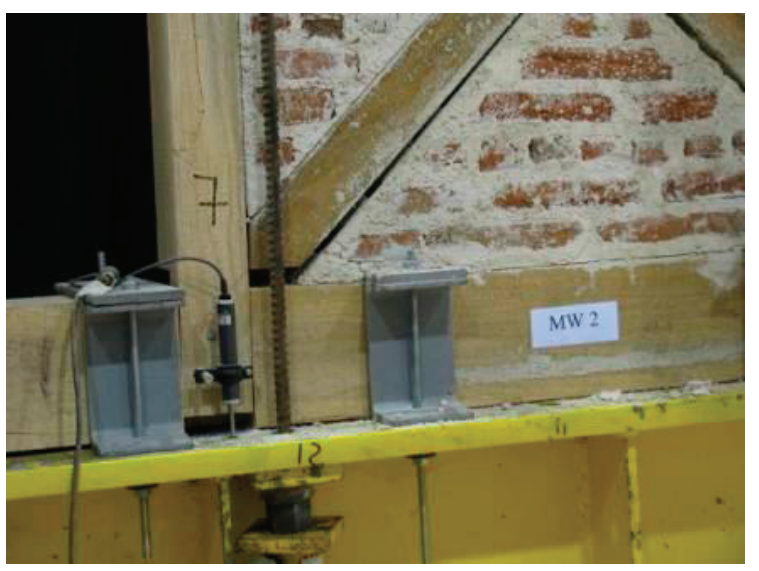

Figure 5. Vertical lift of bottom beam and vertical member.

not completely eliminated, becoming more significant with the increase of the overall deformation (Figure 5).

Figure 6 shows the failure modes of these models. Rupture in MW1 is associated with compression of the diagonals that caused the shear failure at the intermediate beam. In the case of the model MW2 the wall had an early rupture by longitudinal shear of the timber fibres at one end of the intermediate beam, adjacent to the cross-halving joint.

\subsection{Walls reinforced with an elastic-plastic damper}

The reinforcement of TFW and, particularly, the increasing in energy dissipation capacity may ensure an improvement in the building seismic behaviour. The reinforcement adopted aimed at strengthening this structure with an economical and feasible system that may be used in practice. An elastic-plastic steel damper was analysed, consisting of steel bars and rods which ensure increased energy dissipation. These dampers operate along a diagonal of

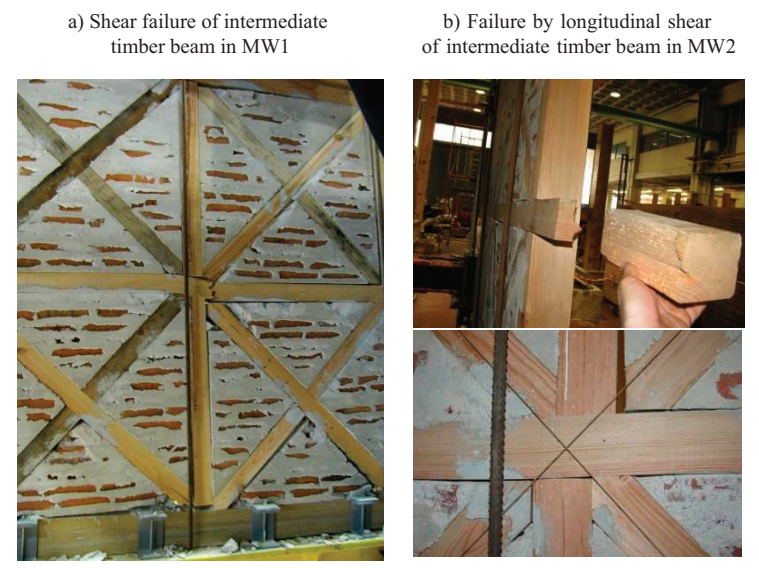

FIGURE 6. Failure mode of masonry walls MW1 and MW2.

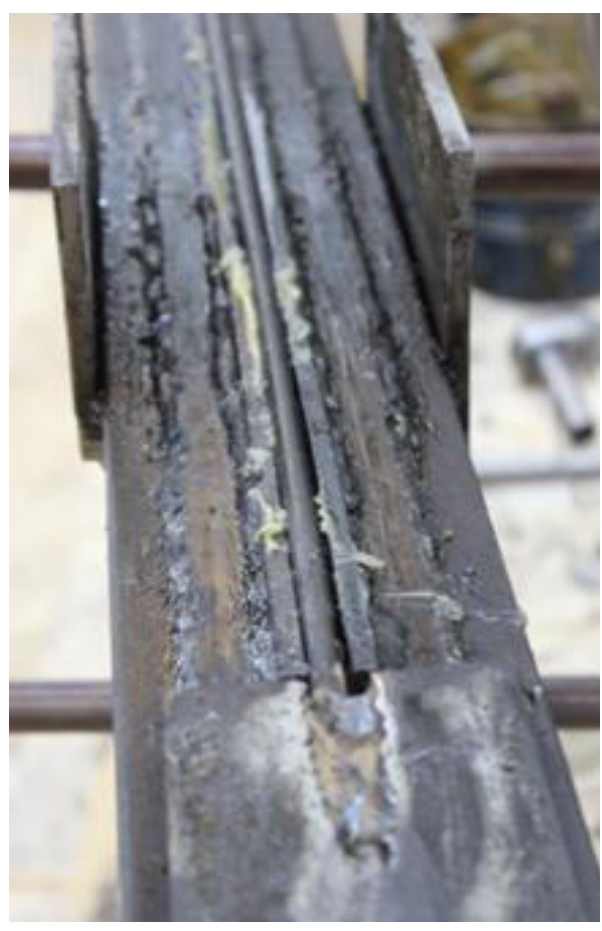

FIgURE 7. Guides, rod and plate.

the walls where the maximum deformation for a certain shear deformation occurs.

The damper itself was composed by a steel rod $(8 \mathrm{~mm}$ diameter, $55.5 \mathrm{~cm}$ length), laterally restrained by steel plates and profiles according to the scheme presented in Figure 8. The rod was placed within a runway in which it can move freely in the axial direction, preventing the occurrence of bending. The runway is constituted by the two UNP100 profiles and the steel plates welded to them (Figures 1b, 7 and 8).The relative displacement between the device ends are fully transmitted to the $\phi 8 \mathrm{~mm}$ steel rod.

In order to obtain the mechanical properties of the damper, such as strength, elastic modulus and energy dissipation, cyclic tests were carried out in a

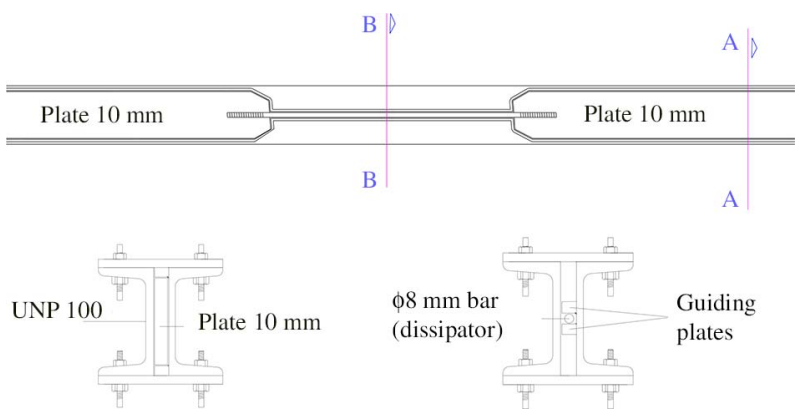

FIGURE 8. Scheme of damper. 


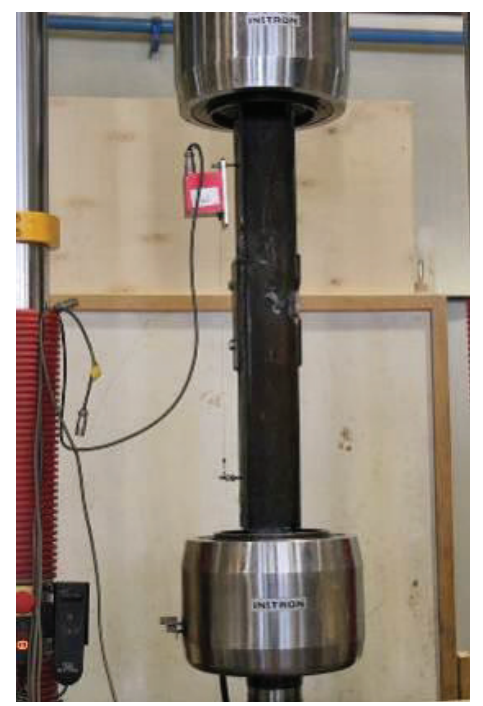

Figure 9. Damper test.

universal Instron testing machine, at a load speed of $0.05 \mathrm{~mm} / \mathrm{s}$ (Figure 9). The results of the cyclic tests are presented in Figure 10 showing a good energy dissipation capacity.

The damping coefficient for a given cycle may be estimated based on equation [2]:

$$
\zeta=\frac{2 E_{d}}{\pi E_{e p}}=\frac{E_{d}}{2 \pi F_{\text {max }} d_{\text {max }}}
$$

Equation [2] computes the equivalent viscous damping coefficient for a hysteretic (elastic-plastic) damper, given by the ratio between two times the energy dissipated in a certain hysteretic cycle $\left(E_{d}\right.$, that corresponds to the area within the loaddisplacement curve) and $\pi$ times the energy dissipated in an equivalent perfect elastic-plastic cycle $\left(\mathrm{E}_{\mathrm{ep}}\right.$, that corresponds to 4 times the product

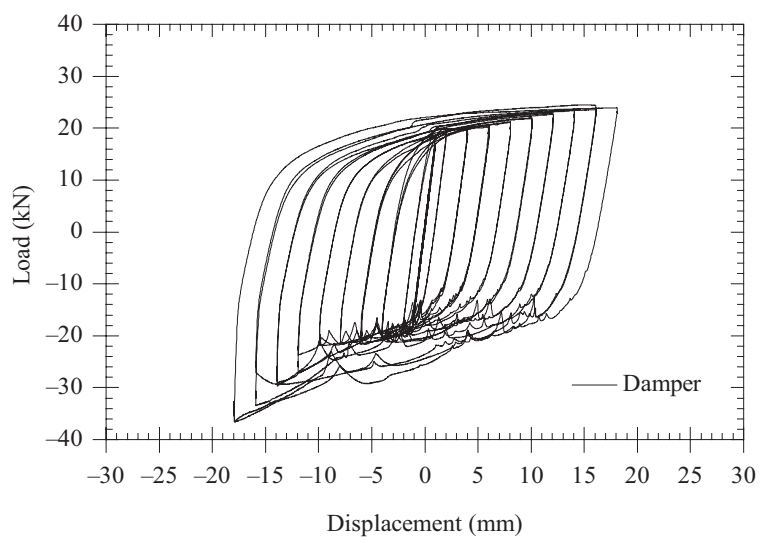

Figure 10. Cyclic response of the damper (compression is positive).

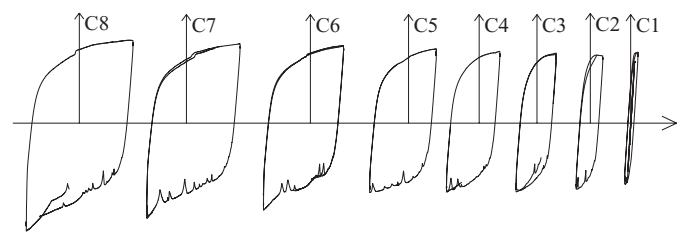

Figure 11. Groups of load cycles in the damper.

between the maximum load $\mathrm{F}_{\max }$ and the maximum deformation $\mathrm{d}_{\max }$ during that cycle).

Figure 11 (individual damper cycles) and Table 3 (calculation of damping coefficient) show that the damper has a significant energy dissipation capacity, typical of mild steel. In table $3, \mathrm{~d}_{\max }$ is the maximum displacement in the cycle, $F_{\text {tension }}, F_{\text {compr }}$ and $\mathrm{F}_{\text {max,average }}$ are the maximum load in tension and in compression and the respective average, $E_{d}$ is the dissipated energy and $\zeta$ is the damping coefficient.

The timber framed walls reinforced with elasticplastic steel dampers placed diagonally in the structure, MW 4 and MW5, were analysed. Figure 12 shows the location and orientation of the loading and displacements measured by instrumentation of these walls.

The experimental testing consisted of submitting the walls to the cyclic displacements history formerly (Table 2) described until rupture occurs. The load-displacement diagrams regarding the tested walls and the dampers themselves presented in Figure 13 show that the damper installed on wall MW5 showed a better performance than that installed on MW4.

Figure 13a shows that some energy dissipation occurred in the first cycles of MW4 damper. However, the rod runway system welding collapsed during the test and, as a consequence, the rod buckled and no more energy dissipation occurred (Figure 14a). Because of this occurrence, the test results of MW4 were disregarded. This shows the importance

TABLE 3. Energy dissipated and damping coefficient in each cycle

\begin{tabular}{lcccccc}
\hline Cycle & $\begin{array}{c}\mathbf{d}_{\text {max }} \\
(\mathbf{m m})\end{array}$ & $\begin{array}{c}\mathbf{F}_{\text {tension }} \\
(\mathbf{k N})\end{array}$ & $\begin{array}{c}\mathbf{F}_{\text {compr. }} \\
(\mathbf{k N})\end{array}$ & $\begin{array}{c}\mathbf{F}_{\text {max,average }} \\
(\mathbf{k N})\end{array}$ & $\begin{array}{c}\mathbf{E}_{\mathbf{d}} \\
(\mathbf{k N . m m})\end{array}$ & $\begin{array}{c}\boldsymbol{\zeta} \\
(\%)\end{array}$ \\
\hline C1 & 2 & 19.9 & -20.0 & 19.9 & 51.8 & 20.8 \\
C2 & 4 & 20.5 & -20.9 & 20.7 & 269.6 & 52.3 \\
C3 & 6 & 21 & -21.5 & 21.3 & 314.2 & 39.2 \\
C4 & 8 & 21.6 & -22.0 & 21.8 & 445.2 & 40.6 \\
C5 & 10 & 21.8 & -22.2 & 22.0 & 599.2 & 43.3 \\
C6 & 12 & 22.7 & -27.1 & 24.9 & 790.0 & 42.1 \\
C7 & 14 & 23.5 & -29.9 & 26.7 & 956.0 & 40.7 \\
C8 & 16 & 24.5 & -33.5 & 29.0 & 1222.0 & 41.9 \\
\hline
\end{tabular}


a) Wall MW5

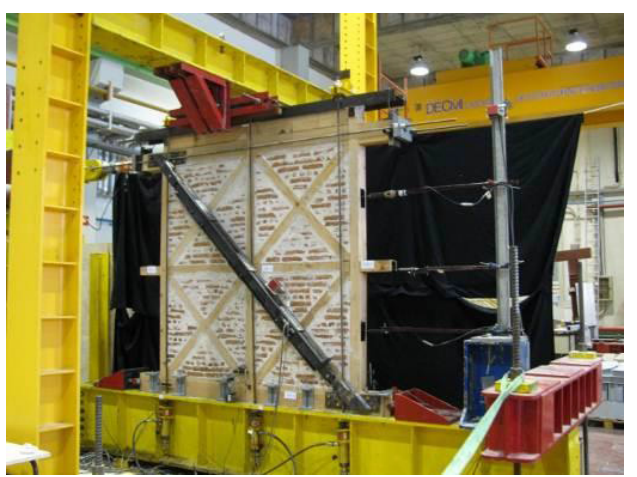

b) Schematic drawing of walls

MW4 and MW5

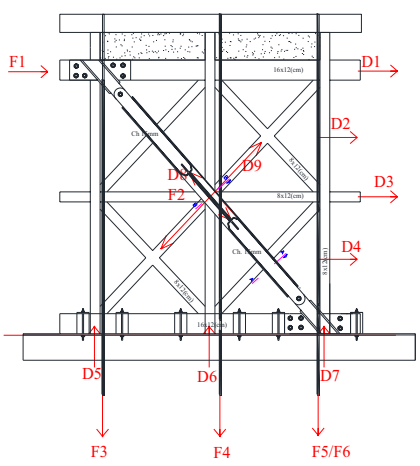

FIGURE 12. Walls MW4 and MW5.

a) Load-displacement diagram of wall specimens

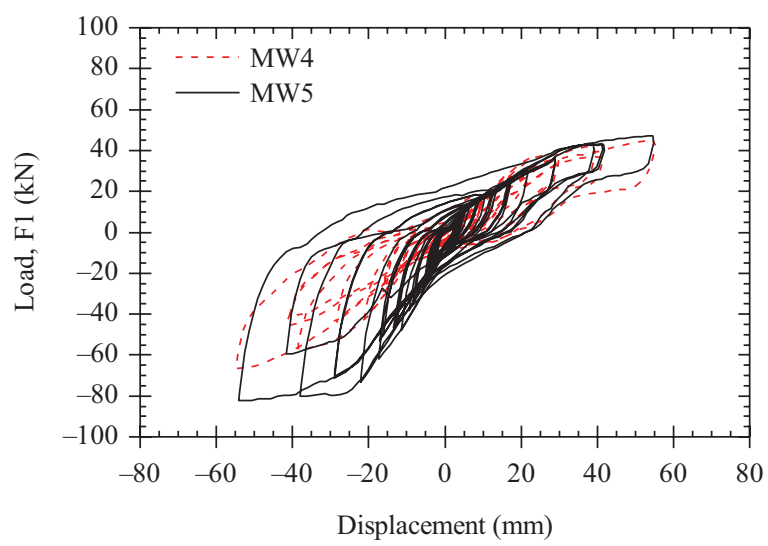

b) Load-deformation diagram of the dampers

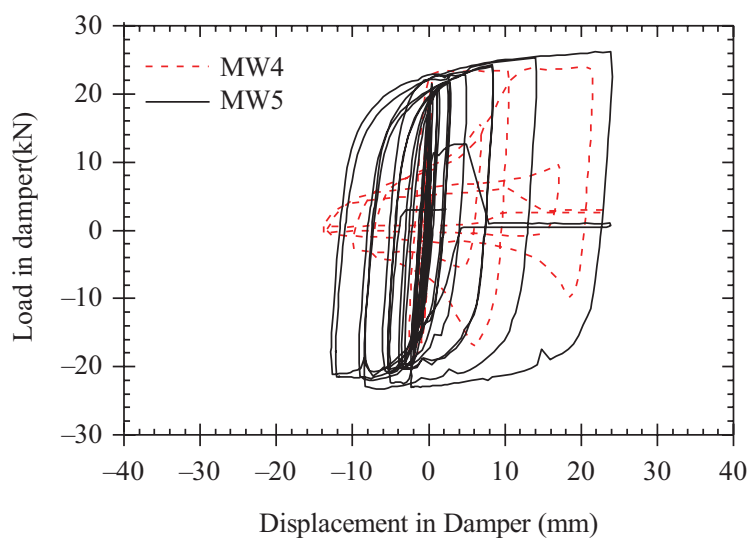

FIgURE 13. Comparison of specimens with dampers MW4 and MW5.
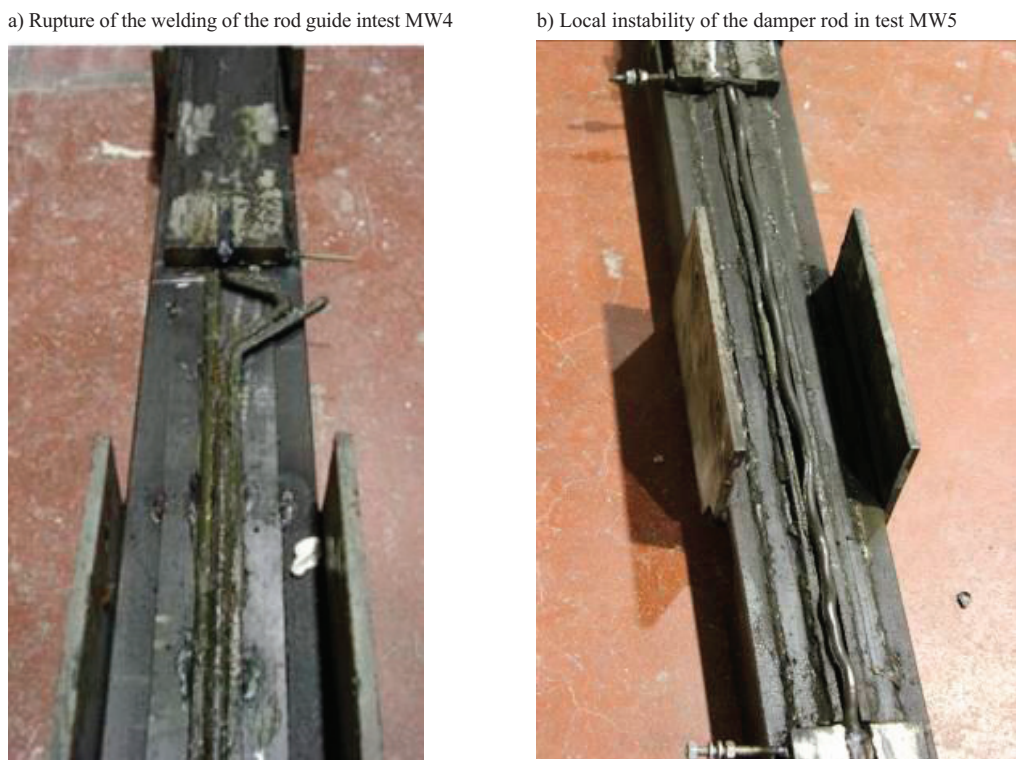

FIGURE 14. Rupture of the welding and instability of the damper rod. 
a) Load-displacement curves of MW1 and MW5

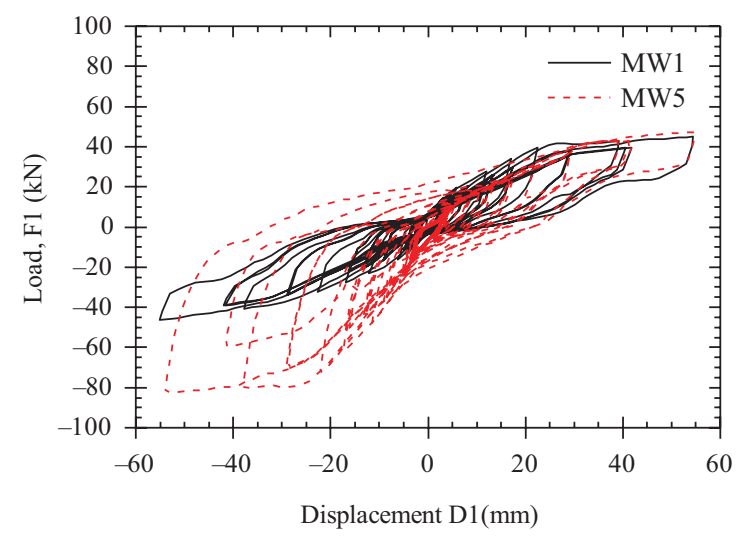

b) Load-displacement curve of MW5 together with damperload -deformation diagram

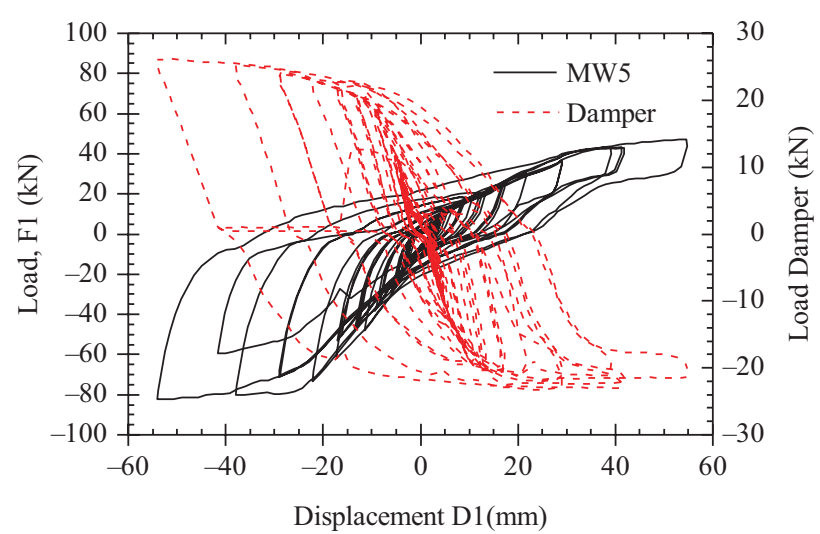

Figure 15. load -displacement curves of MW5 and MW1 walls.

of implementing a quality control procedure when manufacturing these devices.

The energy dissipation in the MW5 wall occurred both in tension and compression, as observed in Figure 13a) although a significant asymmetry is noticeable, due to the localized buckling which the rod undergoes in compression (Figure 14b). This results in better energy dissipation during the tension phase than in compression (Figure 13a). Note that the damper undergoes compressive (negative) deformation when the wall undergoes positive displacements.

Figure 14 shows the welding failure in the test element MW4 (Figure 14a) and the (controlled) localized buckling of the damper rod in the element MW5 (Figure 14b).

The load-displacement curves of tests MW1 and MW5, respectively unreinforced wall and wall reinforced with the functioning damper, are shown in Figure 15. The maximum strength values are $82.3 \mathrm{kN}$ for the reinforced wall and 46.4 $\mathrm{kN}$ for the unreinforced masonry wall, measured at the displacement of $55 \mathrm{~mm}$, corresponding to a $2.6 \%$ drift.

Figure 16 shows the hysteresis cycles along the tests of MW1 and MW5 and Table 4 presents the respective damping coefficients and the data needed to obtain them. In table $4, d_{\max }$ is the maximum displacement in the cycle, $F_{\text {max }}, F_{\text {min }}$ and $F_{\text {max.average }}$ are the maximum positive and negative load and the respective average, $E_{d}$ is the dissipated energy and $\zeta$ is the damping coefficient. A general increase in the damping coefficient with the growing cycles' amplitude is observed in MW5 (Table 4 and Figure 17), associated to the reinforcement wall (the contrary occurs in the unreinforced wall MW1).

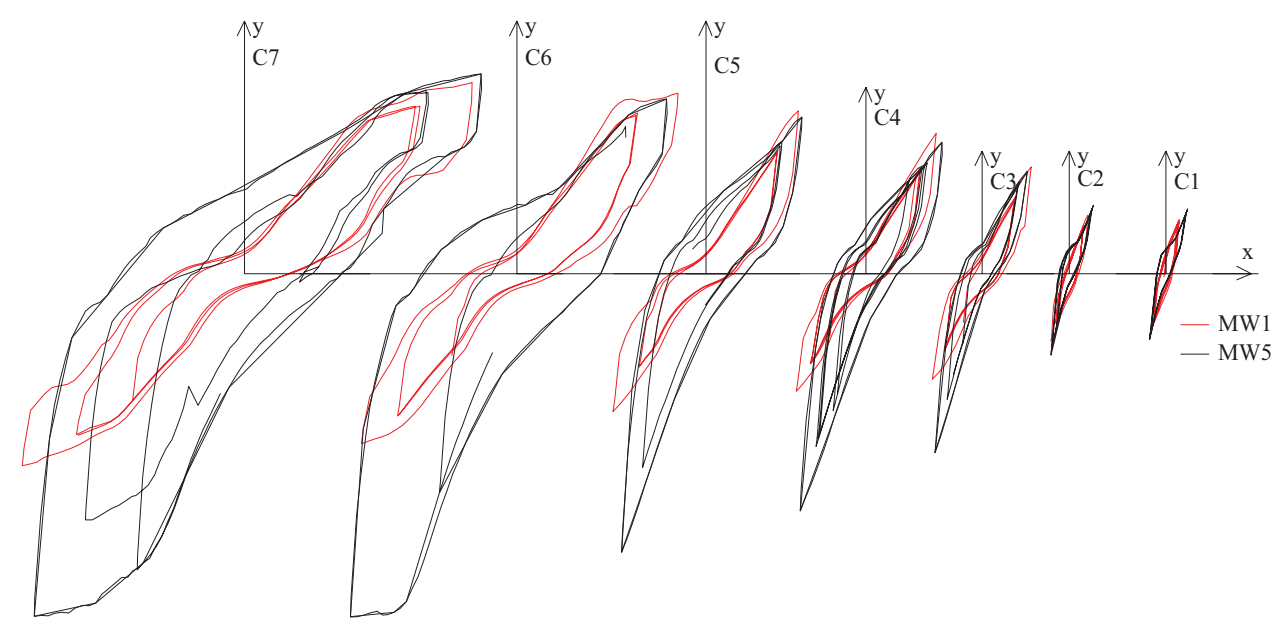

FIGURE 16. Groups of load cycles in the walls MW1 and MW5. 
TABLE 4. Energy dissipated and damping coefficient in each cycle

\begin{tabular}{|c|c|c|c|c|c|c|c|c|c|c|c|c|}
\hline \multirow[b]{2}{*}{ Cycle } & \multicolumn{6}{|c|}{ MW1 } & \multicolumn{6}{|c|}{ MW5 } \\
\hline & $\begin{array}{r}\mathbf{d}_{\max } \\
(\mathrm{mm})\end{array}$ & $\begin{array}{l}F_{\max } \\
(\mathbf{k N})\end{array}$ & $\begin{array}{l}F_{\min } \\
(\mathbf{k N})\end{array}$ & $\underset{\text { max,average }}{(\mathbf{k N})}$ & $\begin{array}{c}\mathbf{E}_{\mathrm{d}} \\
(\mathbf{k N . m m})\end{array}$ & $\begin{array}{c}\zeta \\
(\%)\end{array}$ & $\begin{array}{c}\mathbf{d}_{\max } \\
(\mathrm{mm})\end{array}$ & $\begin{array}{l}\mathbf{F}_{\max } \\
(\mathrm{kN})\end{array}$ & $\begin{array}{l}\mathbf{F}_{\operatorname{mim}} \\
(\mathbf{k N})\end{array}$ & $\begin{array}{c}\mathbf{F}_{\text {max,average }} \\
(\mathbf{k N})\end{array}$ & $\begin{array}{c}\mathbf{E}_{\mathrm{d}} \\
(\mathbf{k N . m m})\end{array}$ & $\begin{array}{c}\zeta \\
(\%)\end{array}$ \\
\hline $\mathrm{C} 1$ & 4.5 & 17.0 & -13.1 & 15.1 & 69.3 & 16.1 & 3.8 & 8.0 & -19.0 & 13.5 & 51.1 & 15.9 \\
\hline $\mathrm{C} 2$ & 5.9 & 19.5 & -16.2 & 17.9 & 97.8 & 14.7 & 4.9 & 9.6 & -25.7 & 17.7 & 64.3 & 11.9 \\
\hline $\mathrm{C} 3$ & 12.0 & 27.5 & -23.3 & 25.4 & 283.8 & 14.9 & 10.9 & 19.3 & -47.9 & 33.6 & 311.4 & 13.5 \\
\hline $\mathrm{C} 4$ & 17.1 & 34.1 & -27.5 & 30.8 & 416.2 & 12.6 & 17.2 & 26.0 & -62.1 & 44.0 & 784.0 & 16.5 \\
\hline $\mathrm{C} 5$ & 22.5 & 39.4 & -32.5 & 35.9 & 610.3 & 12.0 & 21.7 & 30.5 & -73.5 & 52.0 & 1204.0 & 17.0 \\
\hline C6 & 39.2 & 43.1 & -40.8 & 41.9 & 1377.7 & 13.4 & 39.1 & 43.5 & -80.3 & 61.9 & 3104.0 & 20.4 \\
\hline $\mathrm{C} 7$ & 54.4 & 45.1 & -46.4 & 45.8 & 2043.8 & 13.1 & 54.8 & 47.3 & -82.3 & 64.8 & 4755.0 & 21.3 \\
\hline
\end{tabular}

The diagrams presented in Figures 15 and 16 show that the damper has a good capacity to dissipate energy, although under compression the hysteresis is quite smaller than in tension due to the localized buckling that the rod undergoes. This phenomenon leads to increased difficulty in obtaining a symmetrical behaviour, which can be solved by placing one damper in each wall face, in opposed diagonals. This implies, however, an increase in wall thickness, which would be a disadvantage of the strengthening solution.

\subsection{Walls reinforced with steel plates}

Two walls with reinforcing steel plates were tested (MW6 and MW7). The plates were placed in all cross-halving connections between vertical and horizontal timber elements (Figure 21a). The plates were designed to reinforce the connections providing more strength and stiffness but still ensuring deformation and energy dissipation capacity. All plates are $3 \mathrm{~mm}$ thick and have legs connected to each timber element crossing the joint with one M8

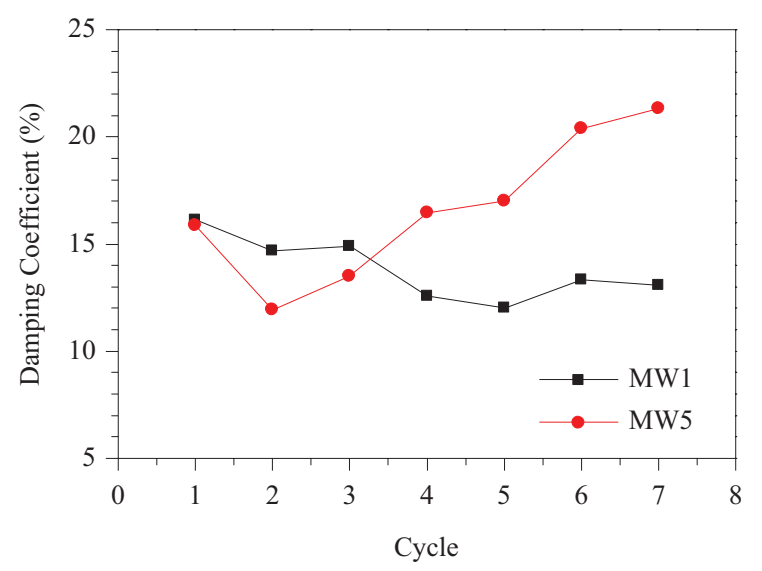

Figure 17. Damping coefficient in the walls MW1 and MW5 in each load cycle. class 8.8 steel bolt. Figure 18 shows the dimensions of the different plates.

In order to obtain the mechanical properties of steel, namely tension strength and elastic modulus, tests were performed on specimens according to the EN 10002-1:2001 (7) (Figure 19). The tests were carried out in a universal Instron testing machine, at a load speed of $0.05 \mathrm{~mm} / \mathrm{s}$ (displacement between grips). The stress-strain diagrams of the plates are presented in Figure 20.

The experimental testing consisted of submitting the walls to the same cyclic displacements history formerly (Table 2) described until rupture occurs. Figure $21 \mathrm{~b}$ ) shows the location and orientation of the loading and displacement measured by instrumentation of the walls MW6 and MW7.

As expected, the behaviour of the walls with reinforcing steel plates resulted in an increased stiffness and energy dissipation (Figure 22). The connection of the timber elements with steel plates promotes an increase in the energy dissipation from the beginning of the test, taking advantage of the geometry of the wall for this purpose. A sudden increase in the wall stiffness occurred for displacements higher than about $60 \mathrm{~mm}$ due to the reasons formerly pointed out and, because of that, those results were discarded. Nevertheless, the $55 \mathrm{~mm}$ displacement corresponds to a $2.6 \%$ drift, which is already quite significant for practical purposes.

Figures 23 and 24 and Table 5 show the energy dissipated in each cycle for specimens MW6 and MW7, together with the results of the MW1 unreinforced wall.

The major conclusions drawn from the results obtained in the walls with reinforcing steel plates in comparison with the unreinforced wall are: i) the load increased for a same displacement, i.e. the walls present a higher stiffness (increase of $126 \%$ : average of $103.1 \mathrm{kN}$ instead of $45.6 \mathrm{kN}$ for a $54 \mathrm{~mm}$ displacement); ii) the energy dissipated in each cycle increased (increase of $254 \%$ in overall 


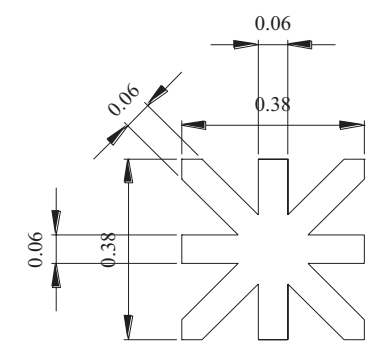

(m)

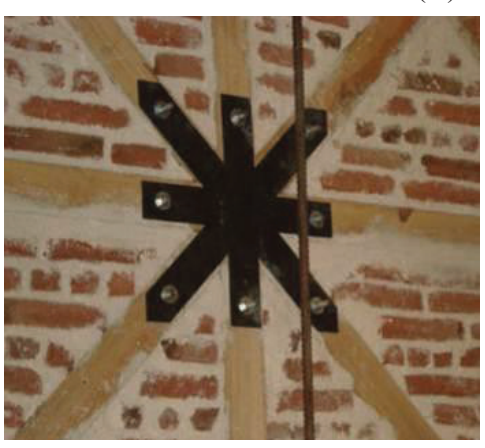

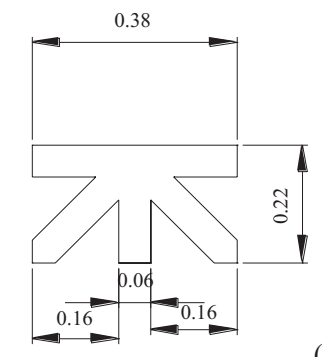

(m)

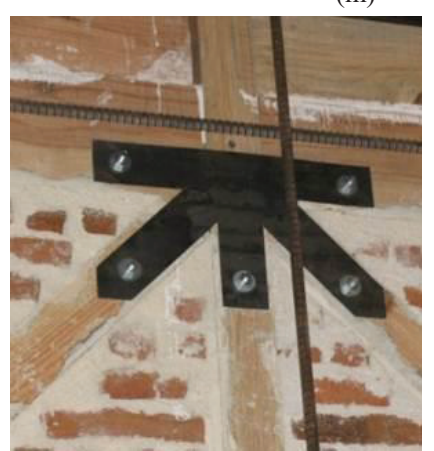

FIGURE 18. Reinforcing steel plates.
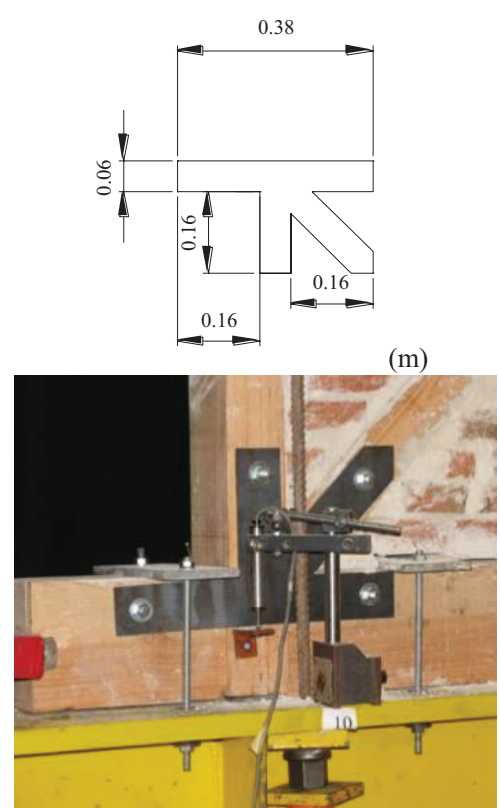

energy dissipation: MW6/7 average value of 17346 $\mathbf{J}$ instead of $4899 \mathrm{~J}$ in MW1); iii) the damping coefficient in each cycle increased, as showed in Figure 24 (increase of 61\%: MW6/7 average value of $22.2 \%$ instead of $13.8 \%$ in MW1). All these differences show a better behaviour of the reinforced walls when subjected to an earthquake load.

The effect of the timber plate's reinforcement involves highly non-linear behaviour associated with: (i) the deformation of the plates, including plasticity, instability and stress concentration phenomena; (ii) the behaviour of the bolts (ditto); (iii) the timbertimber contact in the cross-halving joint connections; and (iv) the interaction between the steel plates

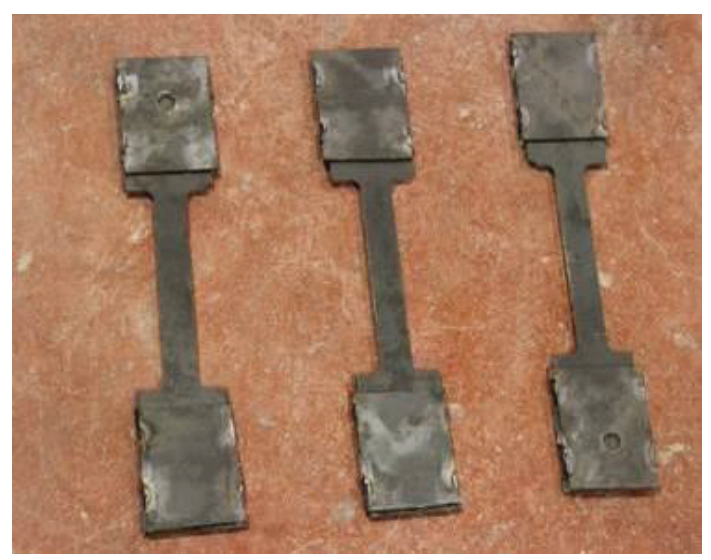

FIGURE 19. Steel specimens. and bolts and the timber elements, including timber plasticization. The numerical simulation of such a reinforced wall must take into account all these complex effects.

\subsection{Wall with reinforced render}

The application of reinforced render is a relatively simple technique that has been used in the strengthening of old buildings walls. The study sought to evaluate the influence of this type of solution in the resistance and energy dissipation capacity of the timber framed walls. The implementation of reinforced render, applied on both

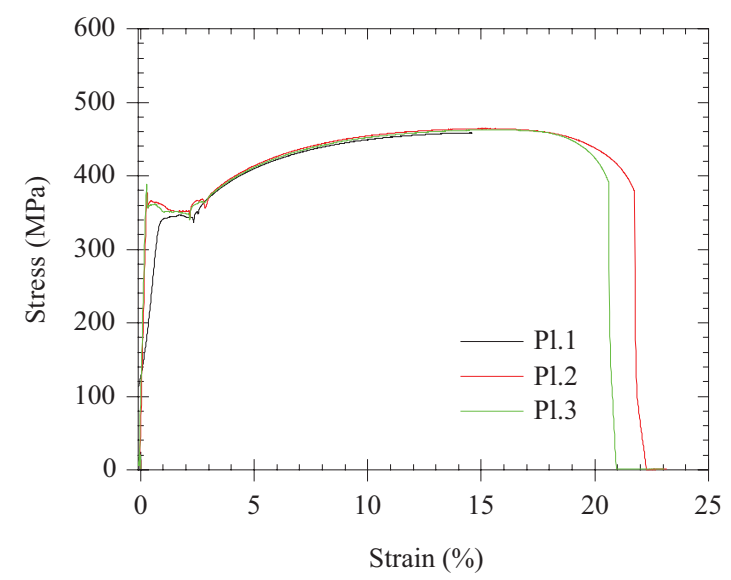

Figure 20. Stress-strain response of $3 \mathrm{~mm}$ steel plates. 

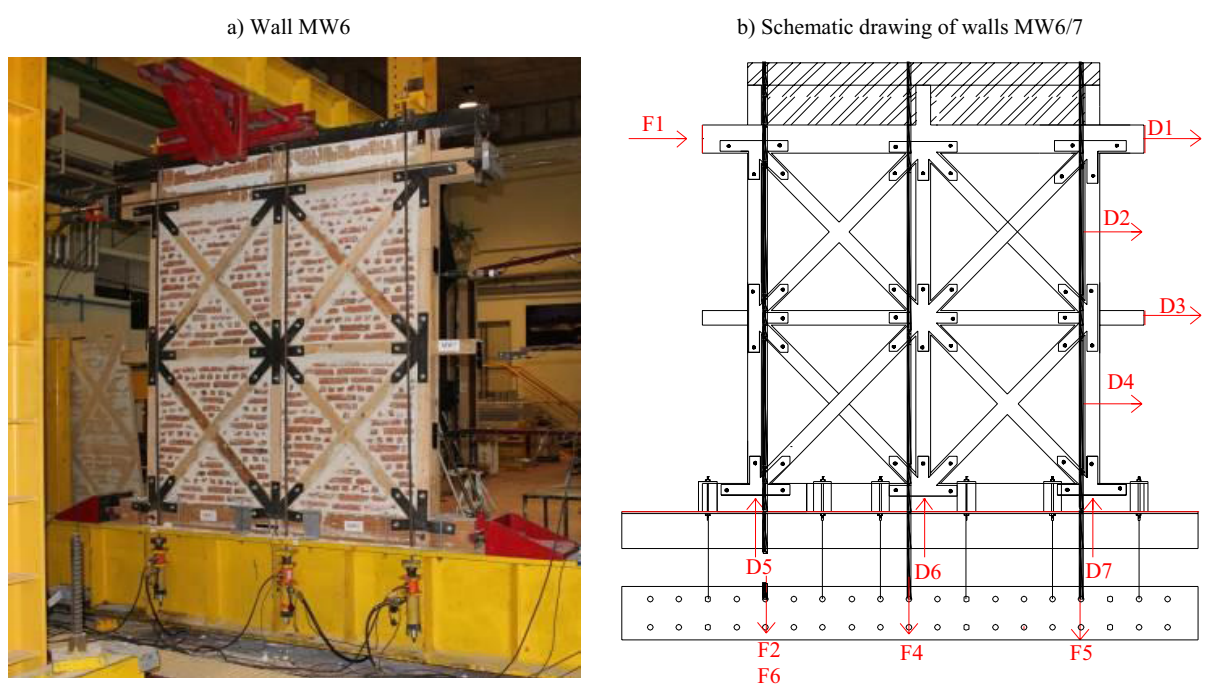

Figure 21. Walls MW6 and MW7.
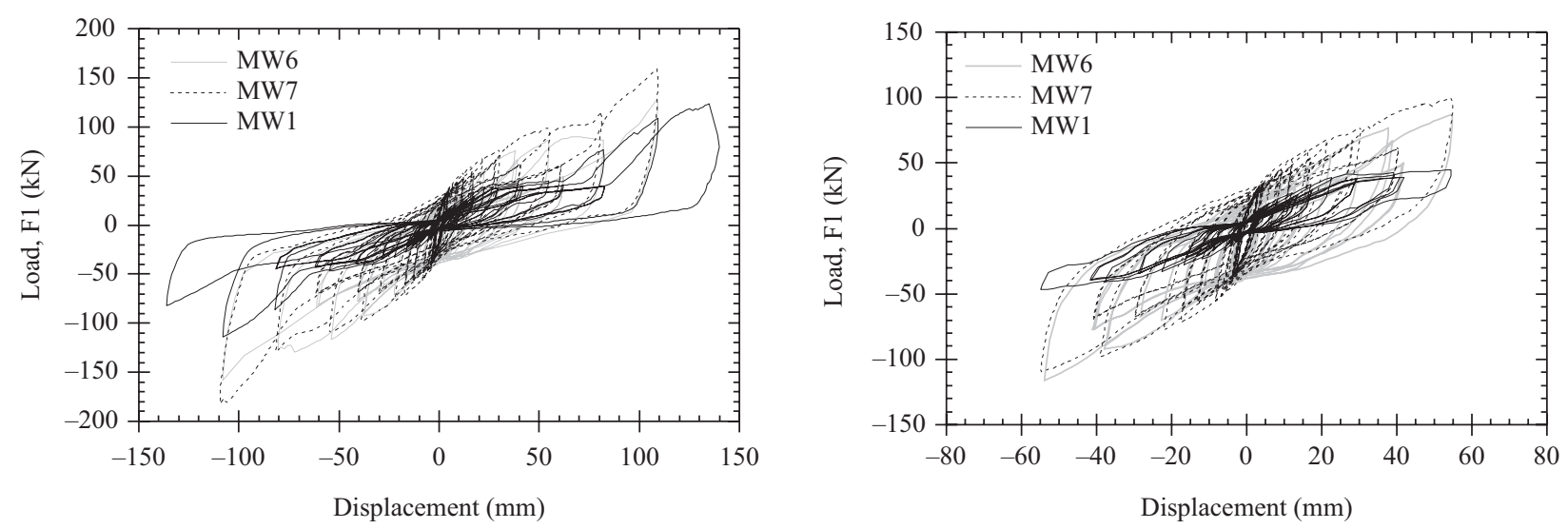

FIGURE 22. Load-displacement curves of MW6, MW7 and MW1walls.

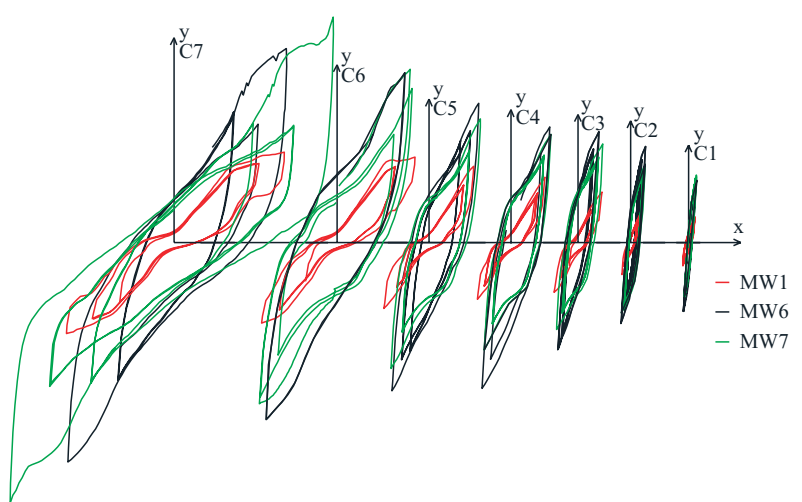

FiguRE 23. Groups of load cycles in the walls MW1, MW6 and MW7.

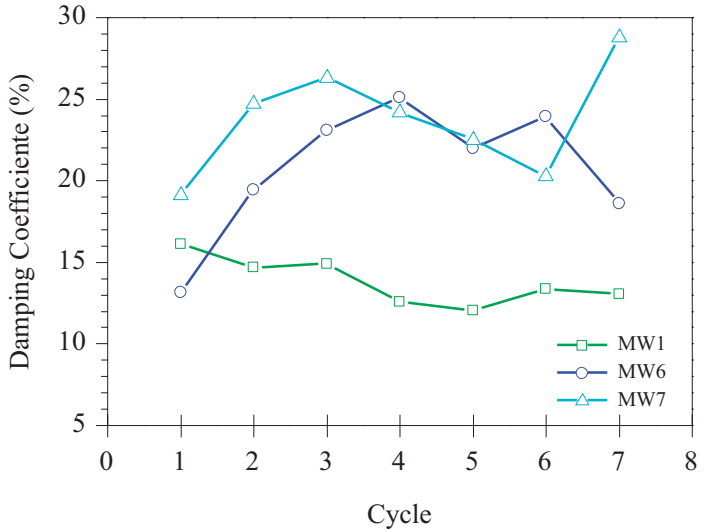

FIGURE 24. Damping coefficient in the walls MW1, MW6 and MW7 in each load cycle. 
TABLE 5. Energy dissipated and damping coefficient in each cycle

\begin{tabular}{|c|c|c|c|c|c|c|c|c|c|c|c|c|}
\hline \multirow[b]{2}{*}{ Cycle } & \multicolumn{6}{|c|}{ MW6 } & \multicolumn{6}{|c|}{ MW7 } \\
\hline & $\begin{array}{c}d_{\max } \\
(\mathbf{m m})\end{array}$ & $\begin{array}{l}\mathbf{F}_{\max } \\
(\mathbf{k N})\end{array}$ & $\begin{array}{l}\mathbf{F}_{\min } \\
(\mathbf{k N})\end{array}$ & $\begin{array}{c}\mathbf{F}_{\text {average }} \\
(\mathbf{k N})\end{array}$ & $\begin{array}{c}E_{d} \\
(k N . m m)\end{array}$ & $\begin{array}{c}\zeta \\
(\%)\end{array}$ & $\begin{array}{c}d_{\max } \\
(\mathbf{m m})\end{array}$ & $\begin{array}{l}\mathrm{F}_{\max } \\
(\mathbf{k N})\end{array}$ & $\begin{array}{l}\mathbf{F}_{\operatorname{mim}} \\
(\mathbf{k N})\end{array}$ & $\begin{array}{c}\mathbf{F}_{\text {average }} \\
(\mathbf{k N})\end{array}$ & $\begin{array}{c}\mathbf{E}_{\mathrm{d}} \\
(\mathrm{kN} \cdot \mathrm{mm})\end{array}$ & $\begin{array}{c}\zeta \\
(\%)\end{array}$ \\
\hline $\mathrm{C} 1$ & 4.1 & 35.3 & -34.1 & 34.7 & 116.8 & 13.2 & 3.1 & 25.8 & -35.7 & 30.8 & 115.0 & 19.1 \\
\hline $\mathrm{C} 2$ & 6.3 & 42.9 & -46.5 & 44.7 & 346.4 & 19.5 & 5.7 & 31.2 & -44.0 & 37.6 & 333.0 & 24.7 \\
\hline $\mathrm{C} 3$ & 10.6 & 45.9 & -55.8 & 50.8 & 780.0 & 23.1 & 11.4 & 40.1 & -53.7 & 46.9 & 880.0 & 26.3 \\
\hline $\mathrm{C} 4$ & 16.2 & 60.6 & -71.7 & 66.1 & 1693.0 & 25.1 & 16.6 & 47.3 & -61.6 & 54.4 & 1376.0 & 24.2 \\
\hline $\mathrm{C} 5$ & 21.3 & 68.1 & -77.2 & 72.7 & 2136.0 & 22.0 & 22.3 & 56.0 & -70.2 & 63.1 & 1987.0 & 22.5 \\
\hline C6 & 30.4 & 77.6 & -97.6 & 87.6 & 4006.0 & 23.9 & 38.8 & 76.7 & -92.3 & 84.5 & 4172.0 & 20.3 \\
\hline $\mathrm{C} 7$ & 54.8 & 99.7 & -109.1 & 104.4 & 6680.0 & 18.6 & 54.7 & 86.9 & -116.4 & 101.7 & 10071.0 & 28.8 \\
\hline
\end{tabular}

sides of the wall MW8 (Figure 25), comprised the following stages:

i. Application of mortar, approximately $2 \mathrm{~cm}$ thick;

ii. Placement of galvanized metal mesh stretched ridge;

iii. Fixation of the metal mesh with nailing through-holes in staggered rows, one per meter, with threaded rods $\varnothing 8 \mathrm{~mm} / 1 \mathrm{~m}$;

iv. Finally, the application of mortar, with $3 \mathrm{~cm}$ thickness.
The galvanized metal mesh stretched ridge is type L62T20/25, with a $25 \mathrm{~mm} \times 62 \mathrm{~mm}$ diamond grid and $2 \mathrm{~mm}$ thickness. The mortar used is based on a Secil commercial dry roughcast product composed by hydraulic binders with lime and siliceous fine aggregates.

In order to obtain the mechanical properties of the studied material, such as strength and elastic modulus, tensile tests were carried out on two specimens of reinforced render (Ra1 and Ra2) with envelope dimensions of $50 \times 45 \times 5 \mathrm{~cm}$ a) Mortar with metal mesh (detail)

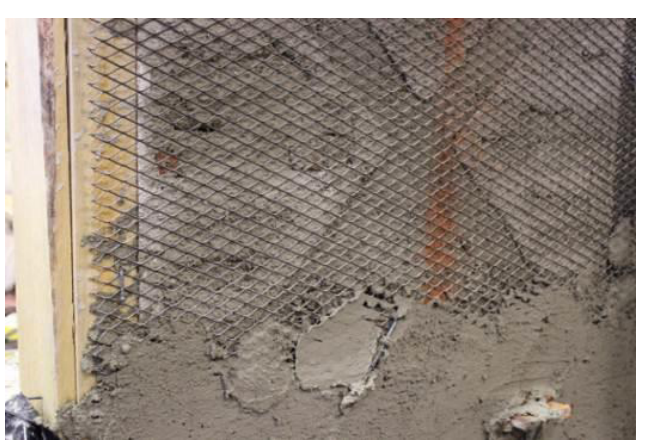

b) Mortar with metal mesh (general view)

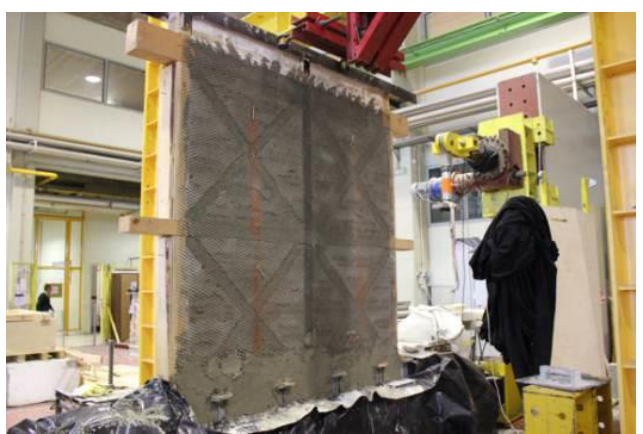

FIGURE 25. Reinforced rendering.
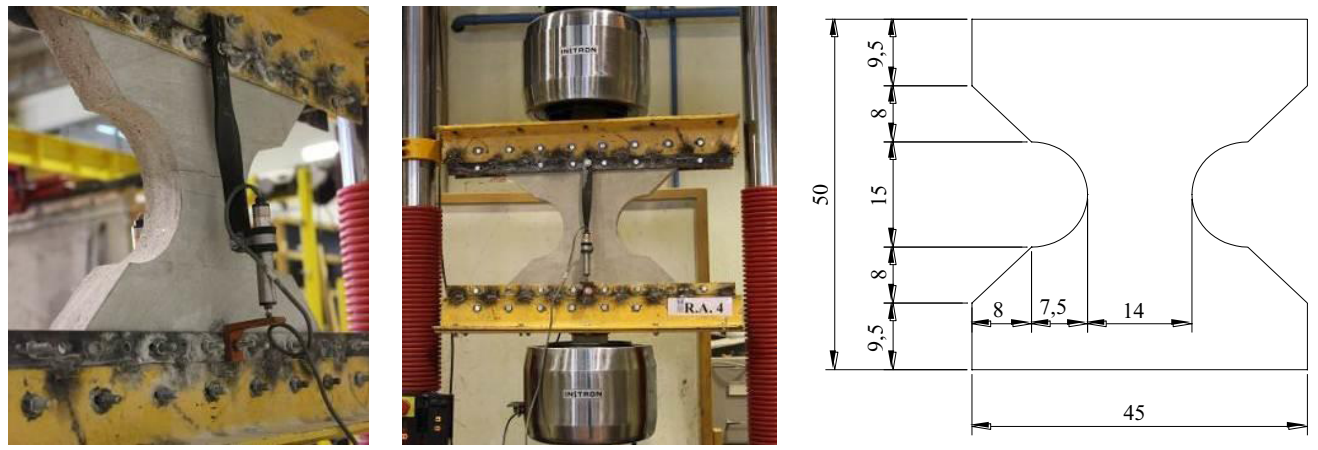

FIGURE 26. Test on the reinforced render specimen (dimensions in $\mathrm{cm}$ ). 


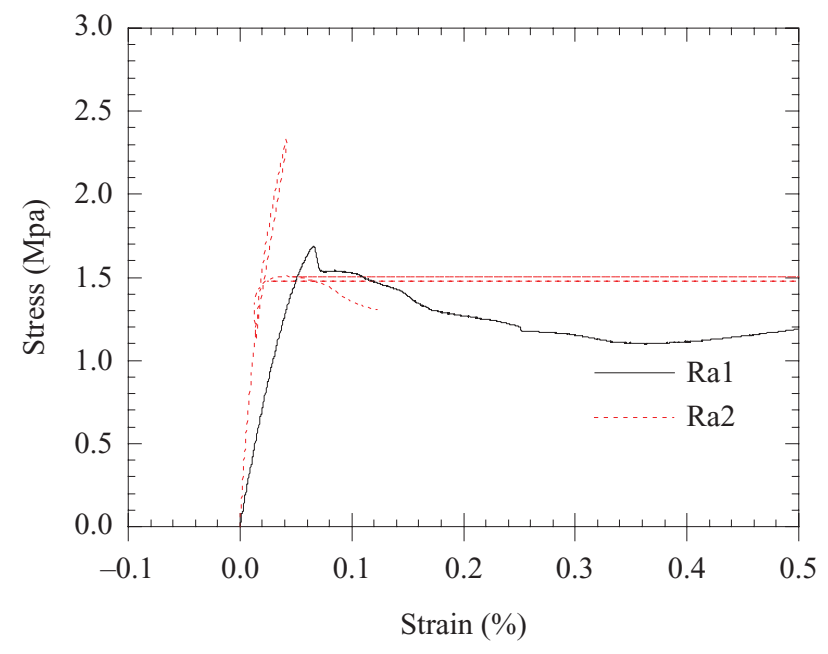

FigURE 27. Stress-strain response for reinforced render specimens.

(Figure 26). The specimens present a circular notch to ensure that the rupture occurs in its smaller section $\left(14 \times 5 \mathrm{~cm}^{2}\right)$ and does not occur in the grips. The tests were carried out in a universal Instron testing machine, at a load speed of $0.05 \mathrm{~mm} / \mathrm{s}$ (displacement between grips). The load was obtained from the press load cell while the element elongation to compute the strain was measured with displacement transducers attached to the specimens' ends. The stress-strain diagrams (Figure 27) show maximum stresses of $2.4 \mathrm{MPa}$ (Ra1) and $1.8 \mathrm{MPa}(\mathrm{Ra} 2)$.

Although the tension strength is not particularly high, the reinforcing steel mesh ensures that its value does not present a sudden decay even if there are any cracks in the mortar due to shrinkage or other phenomenon. Based on these results (tension strength of about $2 \mathrm{MPa}$ ), the overall resistance of the $5 \mathrm{~cm}$ thick reinforced render is estimated as
$100 \mathrm{kN} / \mathrm{m}$, a quite significant value regarding the envisaged purposes.

Figure 28 shows the location and orientation of the loading and displacements measured by instrumentation of wall MW8.

The hysteresis' curves of tests MW1 and MW8 (Figure 29) show that the reinforced wall has an increased stiffness in the first cycles, until $10 \mathrm{~mm}$ displacement. After that, some cracking in the reinforced rendering starts to occur and the load remains constant leading to the loss of stiffness. For a displacement of $40 \mathrm{~mm}$, the corresponding average load is $58.3 \mathrm{kN}$ and $41.9 \mathrm{kN}$ at the reinforced wall and at the simple wall, respectively (Figure 29, Table 6).

Although the reinforced wall presents a higher energy dissipation capacity when compared to the unreinforced wall MW1 (Figure 30 and Table 6), it shows a lower deformation capacity and a similar damping coefficient at the final cycles (Figure 31).

The reinforced render showed lesser efficacy when compared to the other studied solutions, especially because of its lower deformation capacity caused by the collapse mechanism that involved a cut at the base, with a non-efficient use of the reinforcement system.

\section{CONCLUSIONS}

The conclusions of this study may be summarized as follows:

- According to the load-displacement curves, all reinforcement provided a higher ability to dissipate energy and a stiffness increase (Figure 32);

- The elastic-plastic damper (MW5) showed a good behaviour in tension but in the compression cycles some local instability was observed, making this system difficult to implement when performing the rehabilitation;
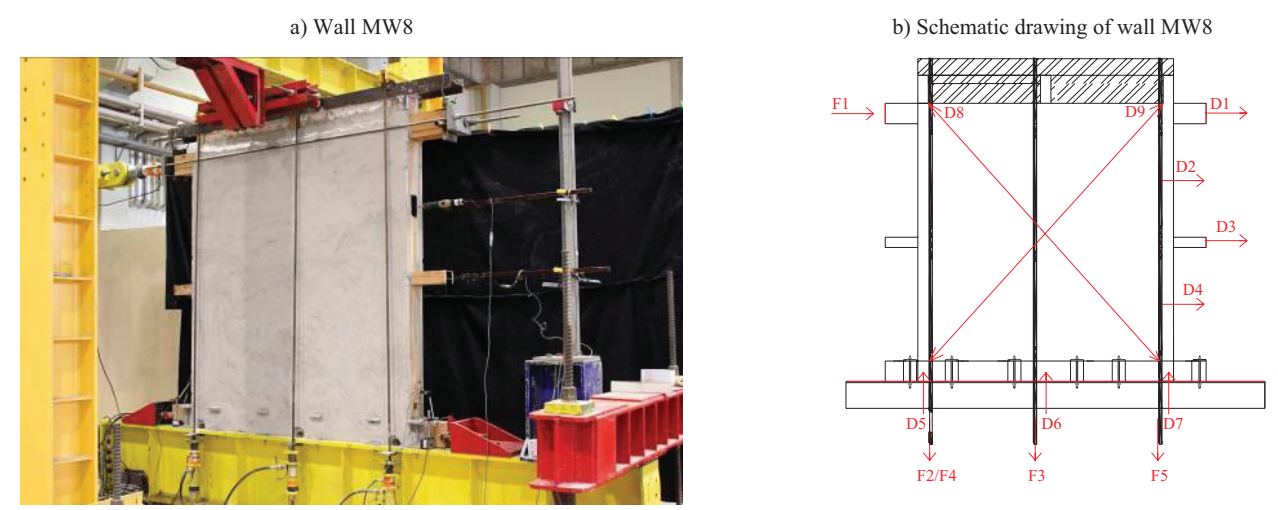

Figure 28. Wall MW8. 


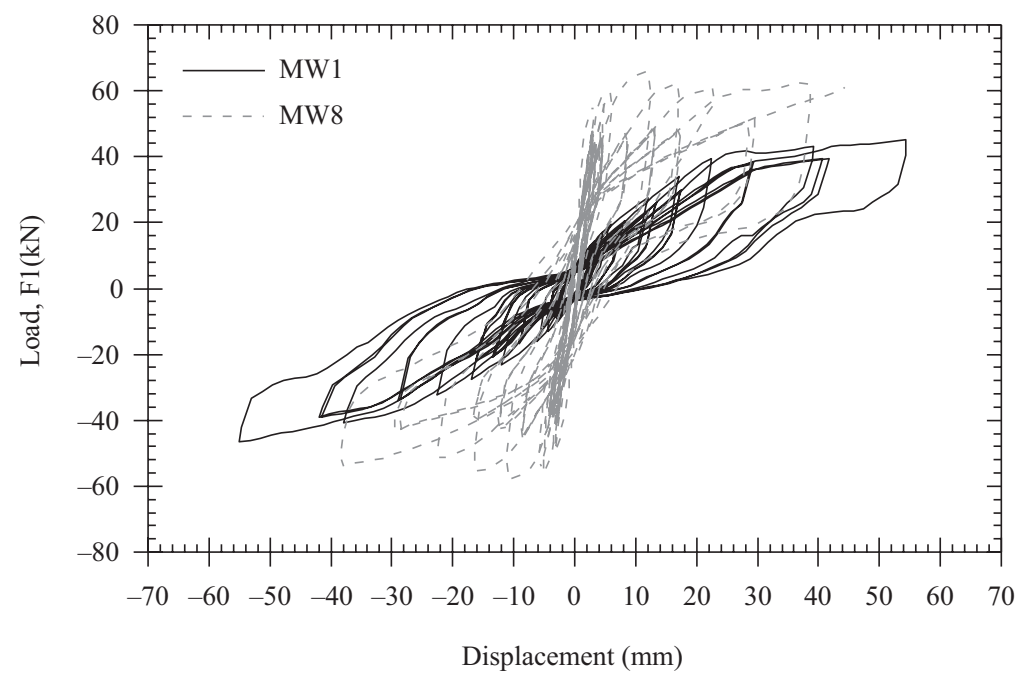

FIGURE 29. Load-displacement curves of MW8 and MW1 walls.

TABLE 6. Energy dissipated and damping coefficient in each cycle

\begin{tabular}{|c|c|c|c|c|c|c|c|c|c|c|c|c|}
\hline \multirow[b]{2}{*}{ Cycle } & \multicolumn{6}{|c|}{ MW1 } & \multicolumn{6}{|c|}{ MW8 } \\
\hline & $\begin{array}{c}\mathbf{d}_{\max } \\
(\mathbf{m m})\end{array}$ & $\begin{array}{l}\mathbf{F}_{\max } \\
(\mathbf{k N})\end{array}$ & $\begin{array}{l}\mathbf{F}_{\min } \\
(\mathbf{k N})\end{array}$ & $\begin{array}{c}\mathbf{F}_{\text {average }} \\
(\mathbf{k N})\end{array}$ & $\underset{(k N . m m)}{\mathbf{E}_{\mathrm{d}}}$ & $\begin{array}{c}\zeta \\
(\%)\end{array}$ & $\begin{array}{c}\mathbf{d}_{\max } \\
(\mathbf{m m})\end{array}$ & $\begin{array}{l}\mathbf{F}_{\max } \\
(\mathbf{k N})\end{array}$ & $\begin{array}{l}\mathbf{F}_{\operatorname{mim}} \\
(\mathbf{k N})\end{array}$ & $\begin{array}{c}\mathbf{F}_{\text {average }} \\
(\mathbf{k N})\end{array}$ & $\underset{(k \mathbf{k} \cdot \mathbf{m m})}{\mathbf{E}_{\mathrm{d}}}$ & $\begin{array}{c}\zeta \\
(\%)\end{array}$ \\
\hline $\mathrm{C} 1$ & 4.5 & 17.0 & -13.1 & 15.1 & 69.3 & 16.1 & 3.0 & 56.0 & -49.4 & 52.7 & 85.1 & 8.5 \\
\hline $\mathrm{C} 2$ & 5.9 & 19.5 & -16.2 & 17.9 & 97.7 & 14.7 & 4.8 & 58.6 & -56.3 & 57.4 & 203.0 & 11.8 \\
\hline $\mathrm{C} 3$ & 12.0 & 27.5 & -23.3 & 25.4 & 283.8 & 14.9 & 12.4 & 65.8 & -57.9 & 61.8 & 781.0 & 16.2 \\
\hline $\mathrm{C} 4$ & 17.1 & 34.1 & -27.5 & 30.8 & 416.2 & 12.6 & 17.1 & 62.9 & -55.3 & 59.1 & 1054.0 & 16.7 \\
\hline $\mathrm{C} 5$ & 22.5 & 39.4 & -32.5 & 35.9 & 610.3 & 12.0 & 22.9 & 61.3 & -51.9 & 56.6 & 1146.0 & 14.1 \\
\hline C6 & 39.2 & 43.1 & -40.8 & 41.9 & 1377.7 & 13.4 & 38.7 & 62.7 & -53.9 & 58.3 & 2430.0 & 17.2 \\
\hline $\mathrm{C} 7$ & 54.4 & 45.1 & -46.4 & 45.8 & 2043.8 & 13.1 & 54.8 & 94.3 & -66.2 & 80.3 & 3566.0 & 12.9 \\
\hline
\end{tabular}

- The strengthening with reinforced render (MW8) led to an increase in stiffness of the wall up to a $10 \mathrm{~mm}$ displacement but afterwards the reinforcement started to open a localized crack at relatively constant load;

- The walls with reinforcing steel plates (MW6 and MW7) at the timber connections showed

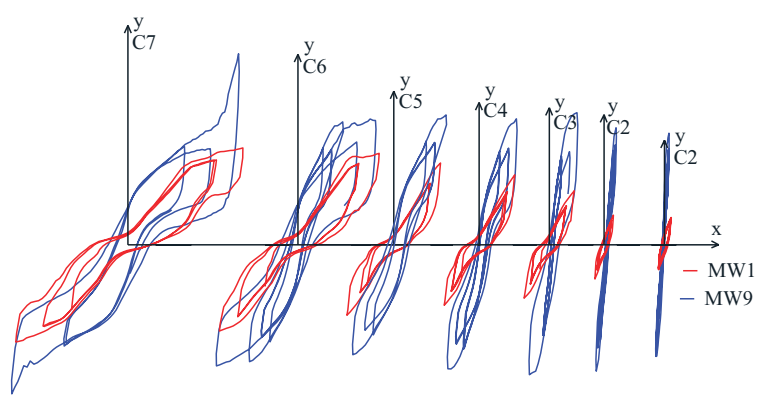

FIGURE 30. Groups of load cycles in the walls MW1 and MW8. the best behaviour in terms of energy dissipation and damping coefficient as well as in stiffness and strength.

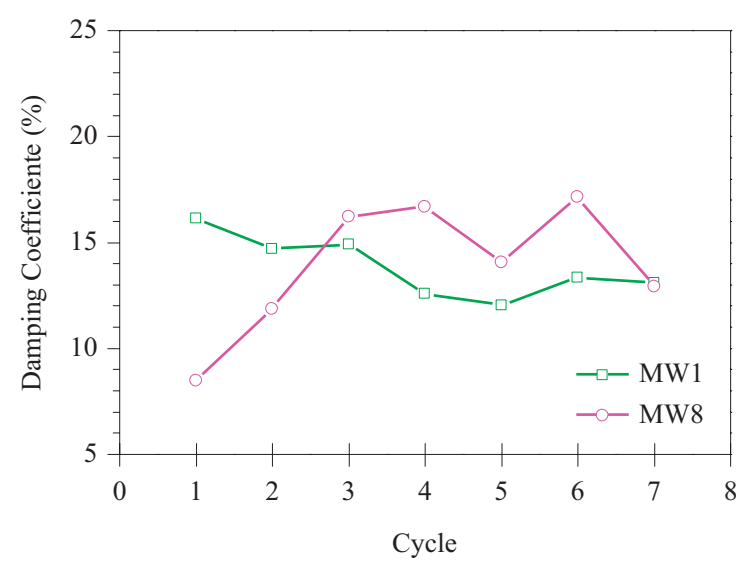

FIGURE 31. Damping coefficient in the walls MW1 and MW8 in each load cycle. 
a) Load-displacement curves in the walls

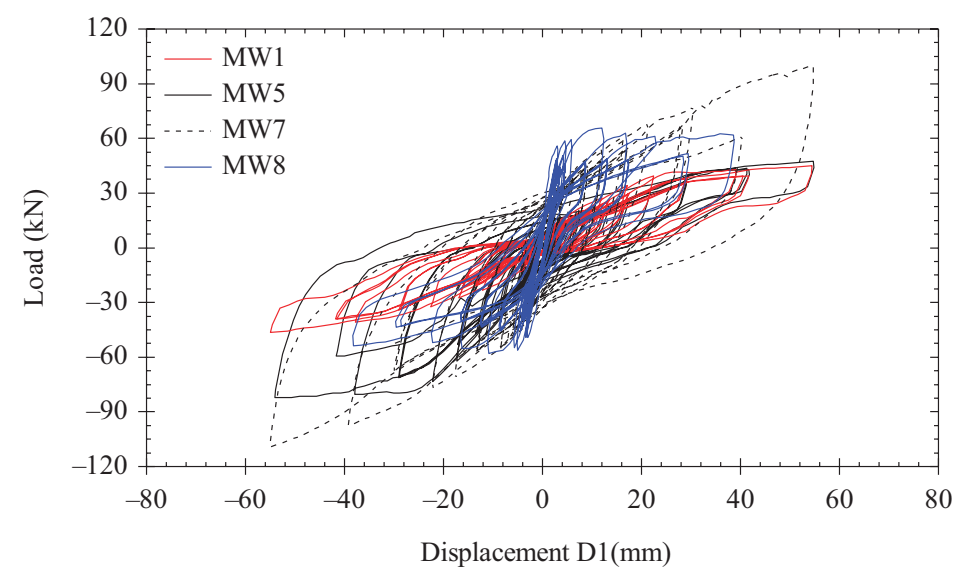

b) Damping coefficientcurves in the walls

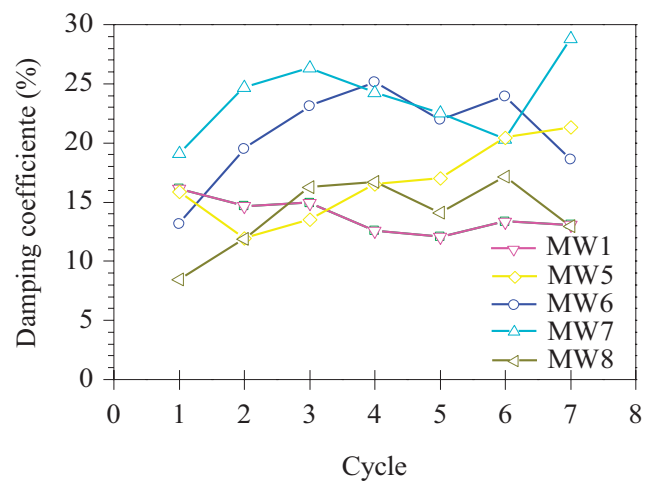

FIGURE 32. Load-displacement curves of walls MW1 (unreinforced wall), MW5 (wall with damper), MW6 and MW7 (wall with steel plates), MW8 (wall with reinforced render).

\section{ACKNOWLEDGEMENTS}

The financial support of the Foundation for Science and Technology (FCT) through the research project PTDC/ECM/100168/2008 - REABEPA is acknowledged. The authors also acknowledge HCI for his invaluable help in the construction of the tested specimens. The laboratory technicians Mr. Fernando Alves and Mr. Fernando Costa are also acknowledged for their help in the experimental tests.

\section{REFERENCES}

1. Duţu, A.; Ferreira, J.; Guerreiro, L.; Branco, F.; Gonçalves, A. (2012) "Timbered masonry for earthquake resistance in Europe", Mater. Construcc. 62 [308], 615-628. http://dx.doi. org/10.3989/mc.2011.01811.
2. Appleton, J. (2003) Rehabilitation of old Buildings, Pathologies and techniques of intervention (in Portuguese). Lisboa: Orion.

3. Ferreira, JG.; Teixeira, M J.: Dutu, A.; Branco, F : Goncalves, A. (2014) Experimental Evaluation and Numerical Modelling of Timber Framed Walls, Experimental Techniques, 38 [44], 45-53, http://dx.doi.org/10.1111/j.1747-1567.2012.00820.x.

4. Krawinkler, H.; Parisi, F.; Ibarra, L.; Ayoub, A.; Medina, R. (2000) Development of a testing protocol for wood frame structures, Krawinkler. CUREE-Caltech Woodframe Project Rep., Stanford University, Stanford, California.

5. Meireles, H.; Bento, R. (2010) Cyclic Behaviour of Pombalino Frontal Walls. Proceedings of the 14th European Conference on Earthquake Engineering (14ECEE), Ohrid, F.Y.R.O.Macedonia.

6. EN 1991-1-1:2002 - Eurocode 1: Actions on structures Part 1-1: General actions - Densities, self-weight, imposed loads for buildings., CEN - European Committee for Standardization, Brussels, 2002.

7. EN 10002-1:2001 -Metallic materials - Tensile testing, Part 1: Method of test at ambient temperature., CEN European Committee for Standardization, Brussels, 2001. 